DOI: $10.31538 /$ ndh.v5i2.617

http://e-journal.ikhac.ac.id/index.php/nidhomulhaq

\title{
PENGARUH MOTIVASI DAN KEPUASAN KERJA TERHADAP KINERJA KARYAWAN PT. KARANGMAS UNGGUL BEKASI
}

\author{
Aldika Rahmandana Saputra ${ }^{1)}$, Parwoto $^{2)}$ \\ ${ }^{1}$ Universitas Mercu Buana \\ 43116210017@student.mercubuana.ac.id \\ ${ }^{2}$ Universitas Mercu Buana \\ pakwoto19@gmail.com
}

\begin{abstract}
Abstrak
Tujuan dari penelitian ini adalah untuk menganalisis pengaruh motivasi kerja dan kepuasan kerja yang ditujukan kepada kinerja para karyawan PT. KarangMas Unggul (KMU) Bekasi. Dalam penelitian ini menggunakan 276 karyawan PT. KarangMas Unggul (KMU) Bekasi sebagai populasi. Dan sampel yang digunakan sejumlah 73 karyawan, dihitung berdasarkan rumus Slovin. Metode pengambilan sampel yang digunakan adalah proporsional stratified random sampling. Metode pengumpulan data menggunakan metode survei, dengan instrumen penelitian berupa kuesioner. Metode analisis data menggunakan Statistik Product and Service Solutions. Penelitian ini membuktikan bahwa motivasi kerja berpengaruh positif dan signifikan terhadap kinerja karyawan. Kepuasan kerja berpengaruh positif dan signifikan terhadap kinerja karyawan.
\end{abstract}

Kata Kunci: Motivasi Kerja, Kepuasan Kerja, Kinerja Karyawan

\begin{abstract}
This study aims to analyze the effect of work motivation and job satisfaction on employee performance. The population in this study were 276 employees of PT. KarangMas Unggul (KMU) Bekasi. The sample used is 73 employees, calculated based on the Slovin formula. The sampling method used was proportional stratified random sampling. Methods of data collection using survey methods, research instruments in the form of a questionnaire. The data analysis method uses Statistical Product and Service Solutions. This study proves that work motivation has a positive and significant effect on employee performance. Job satisfaction has a positive and significant effect on employee performance.
\end{abstract}

Keywords: Work Motivation, Job Satisfaction, Employee Performance

\section{PENDAHULUAN}

Suatu organisasi atau perusahaan membutuhkan figur sentral berupa sumber daya manusia, agar kegiatan manajemen berjalan dengan baik, karyawan atau karyawan merupakan kunci penentu keberhasilan perusahaan atau organisasi tersebut. (Wibowo, Riana \& putra, 2015).

Untuk itu karyawan dituntut memiliki pengetahuan, keterampilan dan kemampuan serta pengalaman, motivasi, disiplin diri, dan semangat kerja yang tinggi sehingga apabila kinerja, prestasi kerja dan kepuasan karyawan baik maka tujuan perusahaan akan meningkat (Yusaini, 2020, p. 33). Mengingat pentingnya sumber daya manusia bagi perusahaan maka diperlukan suatu cara agar karyawan dapat meningkatkan kinerja atau prestasi kerjanya dengan baik untuk menjalankan operasional perusahaan. Agar 
tujuan perusahaan dapat tercapai maka diperlukan adanya hubungan kerja yang saling menguntungkan antara perusahaan dengan karyawannya.

Semua kebijakan dan praktik dalam konsep manajemen sumber daya manusia, melibatkan konsep manajemen secara umum yang fokusnya pada upaya mempengaruhi sumber daya manusia. Jika suatu organisasi ingin bertahan di tengah persaingan yang semakin ketat maka keberhasilan suatu organisasi ditunjukkan dengan kemampuannya dalam mencapai tujuan organisasi.

PT KMU (Karang Mas Unggul) merupakan pabrik dan instalasi baja yang berdiri pada tahun 1990 di ibukota Jakarta. Pabrik ini telah menyediakan banyak proyek di Negara Indonesia bahkan di luar negeri dengan bermitra perusahaan dank lien dari banyak bidang industry dan komersial seperti contoh kimia petro, pembangkit listrik, batubara, semi-konduktor, penyimpanan minyak mentah, bangunan tinggi, bangunan kapal, dan masih banyak lagi. Layanan yang diberikan PT Karang Mas Unggul ini juga meliputi rigging dan pekerjaan baja industry.

Data sekunder tentang variabel kinerja karyawan yang terjadi kepada karyawan di PT. KarangMas Unggul (KMU) Bekasi, yaitu sebagai berikut:
Tabel Penilaian Kinerja Karyawan

\begin{tabular}{lcccccc}
\hline \multicolumn{5}{c}{ Penilaian Kinerja Karyawan } & \\
\hline \multirow{2}{*}{ Keterangan } & \multicolumn{2}{c}{2016} & \multicolumn{2}{c}{2017} & \multicolumn{2}{c}{2018} \\
\cline { 2 - 7 } & Jumlah & Persen & Jumlah & Persen & Jumlah & Persen \\
\hline Sangat Baik & 11 & $5 \%$ & 20 & $8 \%$ & 19 & $7 \%$ \\
\hline \hline Baik & 142 & $62 \%$ & 135 & $57 \%$ & 128 & $46 \%$ \\
\hline \hline Cukup & 47 & $20 \%$ & 50 & $21 \%$ & 69 & $25 \%$ \\
\hline \hline Kurang & 30 & $13 \%$ & 32 & $14 \%$ & 60 & $22 \%$ \\
\hline \hline Total & 230 & $100 \%$ & 237 & $100 \%$ & 276 & $100 \%$ \\
\hline \hline
\end{tabular}

Sumber: Data kinerja karyawan pada PT. KarangMas Unggul (KMU) Bekasi

Dari Tabel di atas dapat dilihat kondisi kenerja karyawan pada PT. KarangMas Unggul (KMU) Bekasi mengalami penurunan pada tingkatan baik setiap tahunnya dari: $62 \%$ pada tahun 2016, $57 \%$ pada tahun 2017, 46\% pada tahun 2018 sedangkan pada tingkatan cukup dari: 20\% pada tahum 2016, 21\% pada tahun 2017, 25\% pada tahun 2018 dan tingkatan kurang dari: $13 \%$ pada tahun 2106, 14\% pada tahun 2017, 22\% pada tahun 2018 mengalami kenaikan pada setiap tahunnya yang membuat terjadi penurunan kinerja di perusahaan.

Berikut adalah hasil pre-survey mengenai beberapa faktor yang memiliki pengaruh penurunan kinerja yang dimiliki karyawan PT. KarangMas Unggul (KMU) Bekasi dari 30 responden sebagai berikut: 
Tabel Hasil Pra Survey Faktor

Mempengaruhi Kinerja Karyawan

\begin{tabular}{lcc}
\hline \multirow{2}{*}{ Variabel } & \multicolumn{2}{c}{ Hasil } \\
\cline { 2 - 3 } & Nominal & Persentase \\
\hline \hline Motivasi & 7 & $23 \%$ \\
\hline \hline Lingkungan Kerja & 2 & $7 \%$ \\
\hline \hline Gaya Kepemimpinan & 2 & $7 \%$ \\
\hline \hline Kepuasan Kerja & 6 & $20 \%$ \\
\hline \hline Disiplin Kerja & 1 & $3 \%$ \\
\hline \hline Budaya Kerja & 3 & $10 \%$ \\
\hline \hline Kompensasi & 3 & $10 \%$ \\
\hline \hline Stress Kerja & 2 & $7 \%$ \\
\hline \hline Pelatihan Kerja & 4 & $13 \%$ \\
\hline \hline Jumlah & 30 & $100 \%$ \\
\hline \hline
\end{tabular}

Sumber: Hasil dari faktor pra survei mempengaruhi kinerja karyawan pada PT. KarangMas (KMU) Bekasi

Dari tabel tersebut diketahui bahwa faktor yang paling mempengaruhi variabel kinerja karyawan adalah penurunan pada PT. KarangMas Unggul (KMU) Bekasi adalah variabel Motivasi sebesar 23\% dan variabel Kepuasan Kerja sebesar 20\% dari 30 responden. Jadi dalam penelitian ini variable yang berpengaruh akan penurunan kinerja karyawan diantaranya adalah variable motivasi dan kepuasan kerja.

Berdasarkan penjelasan diatas maka peneliti menyimpulkan bahwa masih terdapat perbedaan hasil penelitian sehingga perlu diteliti kembali untuk memperkuat hubungan antara variabel motivasi dan kepuasan kerja terhadap kinerja karyawan. Oleh karena itu peneliti semakin yakin untuk mengetahui lebih jauh tentang motivasi dan kepuasan yang diberikan perusahaan kepada seluruh karyawan dan karyawan di tempat kerja. Oleh karena itu peneliti tertarik untuk melakukan penelitian di PT. Karang Mas Unggul (KMU) Bekasi dengan judul "Pengaruh motivasi kerja dan kepuasan kerja terhadap kinerja karyawan pada PT. Karangmas Superior (KMU) Bekasi”.

\section{KAJIAN LITERATUR DAN PEGEMBANGAN HIPOTESIS}

Manajemen Sumber Daya Manusia

Melihat perspektif sumberdaya manusia dari kacamata manajemen, tentu memiliki banyak pengertian yang berkaitan erat dengan manajemen karyawan dan karyawan dalam suatu organisasi atau perusahaan. Beberapa pendapat mengenai pengelolaan sumber daya manusia antara lain Handoko yang menyatakan bahwa pengelolaan sumber daya manusia adalah kegiatan menarik, memilih, mengembangkan, mengevaluasi, memberi penghargaan, dan mengelola anggota atau kelompok pribadi suatu organisasi / perusahaan (Farchan, 2016).

Mangkunegara juga mengemukakan bahwa pengelolaan sumber daya manusia adalah perencanaan, pengorganisasian, pengkoordinasian, pelaksanaan dan pengawasan pengadaan, pengembangan remunerasi, pengintegrasian, pemeliharaan 
dan pemisahan tenaga kerja guna mencapai tujuan organisasi. (Mangkunegara, 2013).

Diharapkan dengan pengelolaan sumber daya manusia, tujuan organisasi dan perusahaan dapat tercapai dengan baik dan efisien. Hal tersebut didukung oleh kedudukan manajemen sumber daya manusia yang sangat penting dalam suatu organisasi.

Berdasarkan pendapat para ahli di atas dapat disimpulkan bahwa manajemen sumber daya manusia merupakan ilmu yang digunakan untuk mengelola karyawan dalam menentukan tujuan organisasi. Proses yang saling berhubungan mulai dari perencanaan, pengorganisasian, koordinasi, pelaksanaan dan pengawasan pengadaan, pengembangan, remunerasi, integrasi, pemeliharaan dan pemutusan hubungan kerja dalam rangka membantu mencapai tujuan perusahaan, individu, organisasi dan masyarakat.

\section{Kinerja Kerja}

Dalam dunia kerja, manusia memiliki banyak potensi untuk terus beraksi dalam berbagai macam aktivitas. Potensi bertindak ini dimiliki oleh manusia sebagai bawaan, namun potensi tersebut hanya diaktualisasikan pada waktu-waktu tertentu. Potensi untuk melakukan sesuatu disebut kemampuan, sedangkan potensi yang menimbulkan ekspresi disebut kinerja.

Kinerja merupakan proses yang memberikan hasil yang mana hasil tersebut mengacu dan terukur selama masa waktu tertentu dengan menitik beratkan pada ketentuan dan kesepakatan yang telah ada (Wijaya, 2015).

Kinerja seseorang juga merupakan ukuran yang mengukur sejauh mana keberhasilan yang telah dicapainya. Ada tiga faktor yang mendasari pengaruh kinerja seseorang, diantaranya yaitu individu, usaha kerja, dan dukungan dari pihak organisasinya (Lestari \& Irbayuni, 2017).

Lebih lanjut dikatakan bahwa pelaksanaan kerja ditentukan oleh interaksi kemampuan dan motivasi. Dari beberapa definisi kinerja di atas dapat disimpulkan bahwa kinerja merupakan hasil kerja yang dapat dikembangkan oleh seseorang atau sekelompok orang dalam suatu organisasi dengan kemampuan dan motivasi untuk melaksanakan pekerjaan sehingga tujuan organisasi dapat terlaksana. keluar dengan benar.

\section{Motivasi Kerja}

Motivasi kerja menurut Hasibuan merupakan bekal sebagai penggerak yang menimbulkan semangat kerja seseorang, sehingga ia berkenan untuk bekerja dengan keras dan bersemangat dalam upaya mencapai hasil yang optimal (Hasibuan, 2014).

Dapat juga dikatakan motivasi kerja sebagai suatu hal yang menjadi pendorong semangat atau bekerja secara individu 
maupun kelompok terhadap suatu pekerjaan agar mudah dalam mencapai tujuan-tujuan yang telah ditentukan (Setyati, 2014).

Ada beberapa psikolog yang memberi pernyataan akan motivasi yang menjadi sebuah konstruksi hipotetis yang dipakai dalam menjelaskan keinginan, arah intensitas, dan perilaku yang diarahkan pada tujuan (Hamzah, 2013).

Dapat kita pahami motivasi dari uraian di atas, merupakan suatu factor yang menggerakkan dan memacu sesorang untuk berperilaku atau beraktifitas sesuai dengan keinginannya. Oleh sebab itu, motivasi kerja sering kali dimaknai sebagai factor sekaligus pemicu seseorang untuk berlaku agar pekerjaannya selalu produktif.

\section{Kepuasan Kerja}

Dalam sebuah pekerjaan, kepuasan kerja dapat dinikmati ketika berada di dalam dan di luar pekerjaan tersebut. Bahkan tidak sedikit kepuasan kerja juga dapat dinikmati baik di dalam maupun di luar suatu pekerjaan (Putra \& Frianto, 2018). Handoko juga berpendapat kepuasan kerja merupakan hal yang dirasa cukup menarik dan penting, sebab dapat dibuktikan dengan adanya manfaat yang dihasilkan terhadap individu, industri dan bahkan masyarakat (Handoko, 2014).

Berdasarkan teori di atas peneliti menyimpulkan bahwa pemahaman kepuasan kerja ini merupakan sebuah perasaan yang dimiliki seseorang dan perasaan itu mendorong atau tidak mendorong personal orang tersebut yang berkaitan dengan pekerjaan yang dia kerjakan baik ketika berada diluar pekerjaan atau di dalam pekerjaan dengan kondisi apapun dari dirinya.

\section{Kerangka Pemikiran}

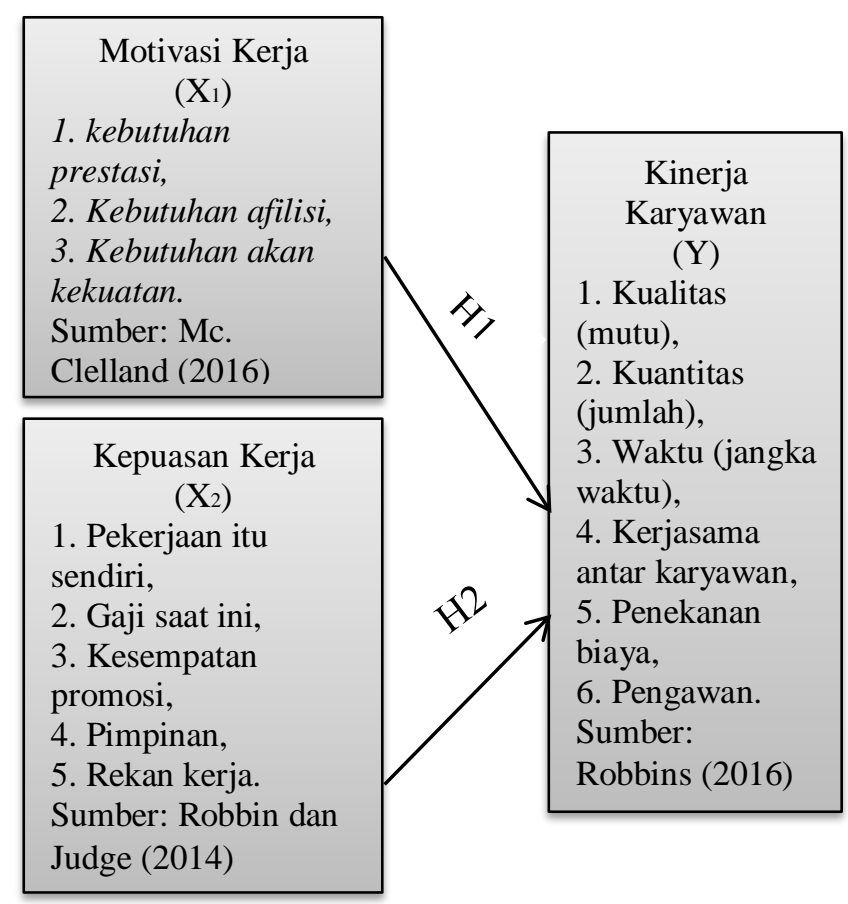

\section{METODE PENELITIAN}

\section{Desain Penelitian.}

Penelitian ini menggunakan desain penelitian kuantitatif kausalitas. Menurut Sugiyono (2017), yaitu suatu desain yang menggalih hubungan antara satu variabel satu dengan variabel lainnya yang mempunyai hubungan sebab akibat. Penelitian ini bertujuan untuk menguji hipotesis tentang pengaruh satu atau 
beberapa variabel terhadap variabel lainnya dengan uji statistik.

\section{Definisi dan Operasional Variabel}

\section{Definisi Variabel}

Variable dapat didefinisikan sebagai suatu bentuk apa pun yang sudah peneliti tentukan untuk dipelajari sehingga mudah dalam mendapatkan informasi yang kemudian ditarik kesimpulan dari informasinya (Sugiyono, 2014). Pada penelitian ini, peneliti menggunakan pengukuran pada beberapa variable dengan cara menggunakan instrument penelitian.

Kemudian langkah selanjutnya, peneliti menganalisis untuk menemukan pengaruh variable yang diteliti. Yang variable tersebut terdiri dari dua macam, diantaranya variable terikat/dependen dan variable bebas/independen (Sugiyono, 2014).

\section{Operasional Variabel}

Operasional variable merupakan dimensi yang dibuat peneliti untuk diberikan pada variable yang mana dimensi itu diberi makna atau merinci sebuah kegiatan yang diperlukan dalam mengukur variable tersebut (Sugiyono, 2014).

Dalam penelitian ini terdapat tiga variable yang menjadi fokus peneliti, diantaranya motivasi sebagai X1 dan kepuasan kerja sebagai X2, dan kinerja karyawan sebagai Y. dan terdapat indicator-indikator yang nantinya diukur menggunakan skala ordinal.

\section{Skala Pengukuran}

Dalam penelitian ini, ada metode yang digunakan untuk pengukuran variable, yaitu metode skala ordinal. Yang dimaksud skala ordinal adalah skala yang digunakan untuk mengukur variable yang tidak hanya menyatakan kategori saja, namun juga peringkat dari konstruk yang diukur (Sugiyono, 2014).

Dalam penelitian ini, peneliti menggunakan skala likert yang merupakan metode pengukuran untuk mengukur sikap, persepsi, dan pendapat seseorang bahkan kelompok tentang kejadian-kejadian social yang ada.

\section{Populasi dan Sampel Penelitian}

1. Populasi Penelitian

Populasi dapat kita pahami sebagai bidang area yang cukup luas, yang di dalamnya terdiri dari obyek maupun subyek yang memiliki bobot dan ciri-ciri khusus yang dipakai peneliti agar mudah dalam memperdalam dan mengkajinya, sehingga proses pengambilan kesimpulan lebih mudah (Sugiyono, 2017).

Dalam penelitian ini, populasi yang kami gunakan adalah para karyawan yang dimiliki oleh PT. KMU/ Karang Mas Unggul, perusahaan yang 
membidangi instalasi dan pabrik baja yang jumlah karyawannya sekitar 276 orang.

2. Sampel dan Teknik Sampling

Sampel merupakan sebagian dari jumlah maupun karakter yang dimilki oleh suatu populasi. Apabila populasi itu besar, dan seorang peneliti tidak mungkin mempelajari semua orang yang ada dalam populasi tersebut, baik karena berbagai macam masalah seperti waktu, dana, tenaga, dan lain lain. Maka perlulah seorang peneliti mengambil sampel dari populasi itu, agar memudahkan untuk dipelajari dan diteliti yang mana kesimpulannya dapat diberlakukan pada seluruh anggota populasi (Sugiyono, 2016)

Kemudian untuk menentukan sampel, teknik yang digunakan oleh peneliti adalah proportional stratified random sampling. Yaitu suatu teknik sampling yang pengampilan sampel pada populasinya itu dengan cara heterogen dan berstrata, sehingga mengambil sampel dari tiap-tiap sub populasi yang kemungkinan jumlahnya pun disesuaikan dengan jumlah anggota populasi, dan dalam pegambilannya acak (Sugiyono, 2016).

Oleh karena itu, sampel yang diambil dari populasi harus benar-benar representatif, yaitu sesuai dengan jumlah dalam populasi pada karyawan PT.
KarangMas Unggul (KMU). Kemudian penentuan besaran sampel berdasarkan rumus Slovin peneliti mendapatkan sebesar sampel sejumlah 73 orang. Dan untuk jumlah anggota sampel yang berstrata, pengambilannya dilakukan dengan cara menggunakan rumus alokasi proporsional.

\section{Metode Analisis Data}

Dalam metode analisi data yang peneliti gunakan dalam penelitian ini, adalah dengan menggunakan program SPSS untuk Windows versi 25. Dan untuk memperoleh data ketika pengolahan data perlu beberapa tahapan, diantaranya uji kualitas; uji validitas; uji reabilitas; uji asumsi klasik; uji normalitas; uji multikolonieritas; uji heterokadastisitas; uji linieritas; uji kesesuaian model; uji koefisien determinasi; uji $\mathrm{F}$ anova; analisi regresi berganda, dan yang terakhir pengujian hipotesis menggunakan uji $\mathrm{t}$ parsial.

\section{HASIL DAN PEMBAHASAN}

\section{Statistik Deskriptif}

Setelah peneliti melakukan penelitian, hasil jawaban dari responden dapat digambarkan dengan table berikut ini: 


\begin{tabular}{clllll} 
Item & $\mathbf{N}$ & $\begin{array}{l}\text { Min } \\
\text { imu }\end{array}$ & $\begin{array}{l}\text { Ma } \\
\text { xim }\end{array}$ & $\begin{array}{l}\text { Mea } \\
\text { m }\end{array}$ & $\begin{array}{l}\text { Std. } \\
\text { Devi }\end{array}$ \\
\hline KK1 & 73 & 1 & 5 & 3.51 & 0.884 \\
\hline KK2 & 73 & 1 & 5 & 3.52 & 0.852 \\
\hline KK3 & 73 & 1 & 5 & 3.79 & 0.849 \\
\hline KK4 & 73 & 1 & 5 & 3.62 & 0.876 \\
\hline KK5 & 73 & 1 & 5 & 3.62 & 0.860 \\
\hline KK6 & 73 & 1 & 5 & 3.70 & 0.811 \\
\hline KK7 & 73 & 1 & 5 & 3.90 & 0.960 \\
\hline KK8 & 73 & 1 & 5 & 3.53 & 0.914 \\
\hline AVG & 73 & 2.50 & 4.75 & 3.64 & 0,481 \\
\hline KK & & & & & \\
\hline Varion
\end{tabular}

Variabel Kinerja Kerja Karyawan

Sumber: Data Primer (diolah dengan program SPSS 25)

Dari table di atas, dapat dilihat rata-rata (mean) dari jawaban para responden untuk variabel kinerja kerja karyawan berada diantara 3,51 (setuju) sampai pada nilai 3,90 (setuju). Rata-rata hitung (mean) dari kinerja karyawan adalah 3,64 yang berarti responden umumnya menjawab setuju pada pernyataan di dalam kuesioner untuk variabel kinerja karyawan. Jawaban responden atas pernyataan KK1 (Saya menyelesaikan hasil kegiatan yang diberikan dengan sangat teliti) mempunyai mean terendah, sedangkan pernyataan KK7 (Perusahaan memiliki inisiatif dalam menyusun rencana anggaran kerja baru) memiliki mean tertinggi.
Deskripsi Jawaban Responden Variabel Motivasi Kerja

\begin{tabular}{llllll} 
Item & $\boldsymbol{N}$ & $\begin{array}{l}\text { Min } \\
\text { imu } \\
\text { m }\end{array}$ & $\begin{array}{l}\text { Ma } \\
\text { xim } \\
\text { um }\end{array}$ & $\begin{array}{l}\text { Me } \\
\text { an }\end{array}$ & $\begin{array}{l}\text { Std. } \\
\text { Devia } \\
\text { tion }\end{array}$ \\
\hline MK9 & 73 & 1 & 5 & 3.48 & 0.884 \\
MK10 & 73 & 1 & 5 & 3.47 & 0.973 \\
MK11 & 73 & 1 & 5 & 3.63 & 0.808 \\
MK12 & 73 & 1 & 5 & 3.48 & 0.818 \\
MK13 & 73 & 1 & 5 & 4.01 & 0.905 \\
\hline MK14 & 73 & 1 & 5 & 3.52 & 0.835 \\
MK15 & 73 & 1 & 5 & 3.63 & 0.890 \\
\hline MK16 & 73 & 1 & 5 & 3.70 & 0.908 \\
\hline $\begin{array}{l}\text { AVG_ } \\
\text { MK }\end{array}$ & 73 & 2.12 & 4.87 & 3.61 & 0.576 \\
\hline
\end{tabular}

Sumber: Data Primer (diolah dengan program SPSS 25)

Dengan hasil dari table di atas, rata-rata (mean) dari jawaban para responden khusu untuk variabel motivasi kerja berada diantara 3,47 (setuju) sampai dengan 4,01 (setuju). Rata-rata hitung (mean) dari motivasi kerja adalah 3,61 yang berarti responden umumnya menjawab setuju pada pernyataan di dalam kuesioner untuk variabel motivasi kerja. Jawaban responden atas pernyataan MK10 (Saya sangat berantusias untuk mencapai berprestasi tinggi dalam bekerja) mempunyai mean terendah, sedangkan pernyataan MK13 (Saya akan selalu berusaha untuk selalu maju dalam hal pekerjaan) memiliki mean tertinggi. 


\begin{tabular}{llllll} 
Item & $\mathbf{N}$ & $\begin{array}{l}\text { Min } \\
\text { imu } \\
\boldsymbol{m}\end{array}$ & $\begin{array}{l}\text { Ma } \\
\boldsymbol{x i m} \\
\text { um }\end{array}$ & $\begin{array}{l}\text { Me } \\
\text { an }\end{array}$ & $\begin{array}{l}\text { Std. } \\
\text { Deviat } \\
\text { ion }\end{array}$ \\
\hline KP17 & 73 & 1 & 5 & 3.44 & 1.014 \\
KP18 & 73 & 1 & 5 & 3.67 & 0.783 \\
KP19 & 73 & 1 & 5 & 3.56 & 0.833 \\
KP20 & 73 & 1 & 5 & 3.70 & 0.893 \\
KP21 & 73 & 1 & 5 & 3.75 & 0.830 \\
KP22 & 73 & 1 & 5 & 3.95 & 0.896 \\
KP23 & 73 & 1 & 5 & 3.78 & 0.901 \\
KP24 & 73 & 1 & 5 & 3.53 & 0.835 \\
AVG_- & 73 & 2.25 & 4.75 & 3.67 & 0.506 \\
KP & & & & & \\
\hline
\end{tabular}

Deskripsi Jawaban Responden Variabel

Kepuasan Kerja

Sumber: Data Primer (diolah dengan program SPSS 25)

Berdasarkan tabel di atas, rata-rata (mean) jawaban responden untuk variabel kepuasan kerja terletak antara 3,44 (setuju) sampai dengan 3,95 (setuju). Rata-rata hitung (mean) dari kepuasan kerja adalah 3,67 yang berarti responden umumnya menjawab setuju pada pernyataan di dalam kuesioner untuk variabel kepuasan kerja. Jawaban responden atas pernyataan KP17 (Melakukan tugas pekerjaan sesuai keahlian) mempunyai mean terendah, sedangkan pernyataan KP22 (Keadilan dari gaji/upah yang diterima setara dengan beban pekerjaan) memiliki rata-rata tertinggi.

\section{Uji Kualitas Data}

\section{Uji Validitas}

Hasil dan Kesimpulan Uji Validitas Hasil Uji Validitas

\section{Variabel Kinerja Kerja Karyawan}

\begin{tabular}{lll}
\hline Pernyata & $\begin{array}{l}\text { Pearson } \\
\text { Correlati }\end{array}$ & Keterang \\
on & 0,563 & Valid \\
\hline KK1 & 0,520 & Valid \\
KK2 & 0,284 & Valid \\
KK3 & 0,623 & Valid \\
KK4 & 0,652 & Valid \\
KK5 & 0,415 & Valid \\
KK6 & 0,621 & Valid \\
KK7 & 0,689 & Valid \\
\hline KK8 & \\
\hline
\end{tabular}

Variabel Motivasi Kerja

\begin{tabular}{|c|c|c|}
\hline MK9 & 0,702 & Valid \\
\hline MK10 & 0,606 & Valid \\
\hline MK11 & 0,678 & Valid \\
\hline MK12 & 0,688 & Valid \\
\hline MK13 & 0,600 & Valid \\
\hline MK14 & 0,744 & Valid \\
\hline MK15 & 0,582 & Valid \\
\hline MK16 & 0,668 & Valid \\
\hline \multicolumn{3}{|c|}{ Variabel Kepuasan Kerja } \\
\hline KP17 & 0,516 & Valid \\
\hline KP18 & 0,605 & Valid \\
\hline KP19 & 0,495 & Valid \\
\hline KP20 & 0,623 & Valid \\
\hline KP21 & 0,594 & Valid \\
\hline KP22 & 0,415 & Valid \\
\hline KP23 & 0,689 & Valid \\
\hline KP24 & 0,723 & Valid \\
\hline
\end{tabular}

Sumber: Data Primer (diolah dengan program SPSS 25) 
Jika merujuk pada table di atas, maka semua pernyataan dari peneliti melalui kuisoner, setiap variable memiliki ketrangan valid sebab ditunjukkan dengan nilai $r$ hitung (Pearson Correlation) lebih dari pada r table yaitu (0.2302).

\section{Uji Realibilitas}

Hasil dan Kesimpulan Uji Realibilitas

\begin{tabular}{lccc} 
Variabel & $\begin{array}{c}\text { Cronba } \\
\text { ch's }\end{array}$ & $\begin{array}{c}\text { Nof } \\
\text { Items }\end{array}$ & Keterangan \\
& $\begin{array}{lcc}\text { Alpha } \\
\end{array}$ & & \\
\hline Kinerja & 0,669 & 8 & Reliabel \\
Kerja & & & \\
Karyawan & & 8 & Reliabel \\
Motivasi & 0,810 & & \\
Kerja & & 8 & Reliabel \\
Kepuasan & 0,717 & & \\
Kerja & & & \\
\hline
\end{tabular}

Hasil Uji Reliabilitas

Sumber: Data Primer (diolah dengan program SPSS 25)

Menurut tabel variabel kinerja kerja karyawan, motivasi kerja, dan kepuasan menunjukkan nilai Cronbach's Alpha lebih besar dari 0,60 yang berarti semua variable untuk penelitian ini dapat dinyatakan reliable. Ini menunjukkan semua pernyataan yang telah dipakai mampu mendapatkan data yang konsisten, yang berarti jika pernyataan tersebut disampaikan lagi maka akan mendapatkan hasilyang kurang lebih sama.

\section{Uji Asumsi Klasik}

1. Hasil dan Kesimpulan Uji Normalitas

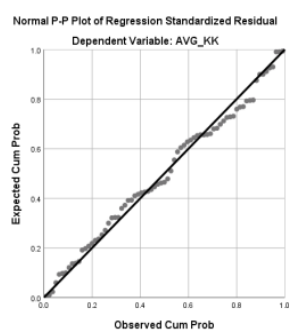

\section{HASIL UJI NORMALITAS}

Sumber: Data Primer (diolah dengan program SPSS 25)

Berdasarkan gambar di atas, dapat diketahui dan dinyatakan bahwa data Normal P-P Plot yang dipakai berdistribusi normal. Hal ini disebabkan semua titik pada gambar distribusi tampak mendekati atau menyebar ke area garis diagonal dan persebaran titik datanya pun searah dengan mengikuti garis-garis diagonal.

2. Hasil dan Kesimpulan Uji Multikolonieritas

Hasil Uji Multikolonieritas

$\begin{array}{ll}\text { Variabel } & \begin{array}{l}\text { Toler } \\ \text { ance }\end{array} \\ \text { Bebas } & \text { VIF }\end{array}$

\begin{tabular}{lll}
\hline Motivasi Kerja & 0.926 & 1.080 \\
Kepuasaan & 0.926 & 1.080 \\
Kerja & & \\
\hline
\end{tabular}

Sumber: Data Primer (diolah dengan program SPSS 25)

Berdasarkan tabel dapat diketahui bahwa ketiga variabel bebas dalam penelitian ini memiliki nilai Tolerance $>0,10$ dan VIF $<10,0$. Dengan demikian, bisa disimpulkan 
tidak ditemukan gejala multikolonieritas pada variabel bebas dalam penelitian ini.

3. Hasil dan Kesimpulan Uji Heterokedastisitas

Hasil Uji Heteroskedastisitas

Variabel Bebas Signifikansi

\begin{tabular}{ll}
\hline Motivasi Kerja & 0,517 \\
Kepuasan Kerja & 0,590
\end{tabular}

Sumber: Data Primer (diolah dengan program SPSS 25)

Melihat table dengan menggunakan metode korelasi spearman's rho, tentu dapat dilihat dari kedua variabel bebas di atas memiliki nilai signifikansi $>0,05$. Mengingat signifikansi lebih besar dari 0,05 maka bisa ditarik kesimpulan bahwa tidak terjadi heteroskedastisitas dalam model regresi ini.

\section{Hasil dan Kesimpulan Uji Linearitas} Hasil Uji Linearitas

\begin{tabular}{lll}
$\begin{array}{l}\text { Variabel } \\
\text { Bebas }\end{array}$ & $\begin{array}{l}\text { Signifik } \\
\text { ansi }\end{array}$ & $\begin{array}{l}\text { Keteran } \\
\text { gan }\end{array}$ \\
\hline $\begin{array}{l}\text { Motivasi } \\
\text { Kerja }\end{array}$ & 0,396 & Linear \\
$\begin{array}{l}\text { Kepuasa } \\
\text { n Kerja }\end{array}$ & 0,297 & Linear \\
\hline
\end{tabular}

Sumber: Data Primer (diolah dengan program SPSS 25)

Mengacu pada tabel tingkat signifikansi, karena mengunakan taraf signifikansi atau $\alpha$ $=5 \%$ maka akan di uji dengan 0,05 , hal ini pada variabel motivasi kerja memiliki signifikan sebesar $0,396>0,05$ maka terdapat hubungan linear secara signifikan antara motivasi kerja dengan kinerja karyawan dan pada variabel kepuasan kerja memiliki signifikan sebesar $0,297>0,05$ maka ada hubungan linear secara signifikan antara kepuasan kerja dengan kinerja karyawan. Karena nilai sig. >0,05 maka dapat memakai model regresi untuk memprediksi tingkat kinerja karyawan.

\section{Uji Kesusaian Model}

1. Hasil dan Kesimpulan Uji Koefisien Determinasi $\left(\mathrm{R}^{2}\right)$

Hasil Uji Koefisien Determinasi $\left(\mathrm{R}^{2}\right)$

\section{R Square Adjusted R Square}

\begin{tabular}{ll}
$\mathbf{0 , 5 8 7}$ & 0,575 \\
\hline
\end{tabular}

Sumber: Data Primer (diolah dengan program SPSS 25)

Berdasarkan tabel diatas nilai Adjusted R Square $\left(\mathrm{R}^{2}\right)$ adalah $0,575=57,5 \%$. Artinya, besarnya pengaruh variabel motivasi kerja dan kepuasan kerja karyawan terhadap variabel independent dalam penelitian ini adalah sebesar $57,5 \%$ dan sisanya sebesar $42,5 \%$ dipengaruhi variabel lain yang tidak tercantum dalam penelitian ini misalnya: karakteristik kepemimpinan, lingkungan kerja, disiplin kerja, kompensasi dan seterusnya.

2. Hasil dan Kesimpulan Uji F

$$
\text { Hasil Uji F ANOVA }
$$

F Hitung Signifikansi

\begin{tabular}{lll}
\hline $\mathbf{4 9 . 6 9 4}$ & \multicolumn{2}{c}{$.000^{\text {b }}$} \\
\hline Sumber: & Data & Primer (diolah
\end{tabular}

menggunakan program SPSS 25) 
Jika melihat pada table di atas, hasil uji F Anova didapatkan F sebesar 49.694dan dengan nilai signifikansi 0,000. Dalam F table ini, dapat dilihat table statistic berada pada tingkat signifikansi 0,05 dengan df 1 (jumlah variabel -1$)=2(\mathrm{~K}=$ variabel $\mathrm{x})$, dan untuk df 2 (jumlah responden $(n)-K$ ) atau $73-2=71-1=70$, sehingga diperoleh hasil untuk F tabel sebesar 3,13.

Kesimpulannya adalah, menggambarkan model regresi yang dipakai ketika uji kesesuaian model untuk penelitian ini telah sesuai dan bisa dipai untuk selanjutnya uji analisis regresi linear berganda serta uji hipotesis/uji t.

E. Hasil dan Kesimpulan Uji Regresi

Hasil Uji Analisis Regresi Linear Bergand a

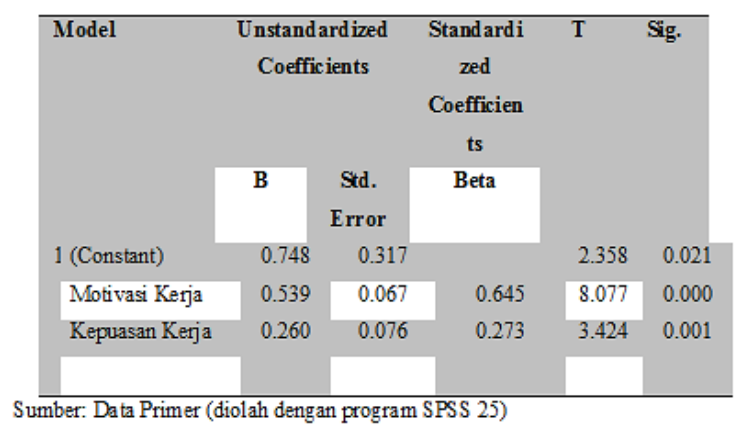

Linear Berganda

Berdasarkan tabel diperoleh persamaan regresi linear berganda sebagai berikut:

$\mathrm{KK}=.645 \mathrm{MK}+.273 \mathrm{KP}$

1. Koefisien regresi variabel motivasi kerja sebesar +.645 menyebutkan bahwa motivasi kerja berpengaruh positif pada kinerja kerja karyawan.

Artinya semakin baik motivasi kerja, maka kinerja kerja karyawan menjadi lebih baik, dan sebaliknya.

2. Koefisien regresi variabel kepuasan kerja sebesar +.273 menggambarkan bahwa kepuasan kerja berdampak positif pada kinerja kerja karyawan. Artinya semakin baik kepuasan kerja, maka kinerja kerja karyawan akan meningkat, dan sebaliknya.

F. Hasil dan Kesimpulan Uji t Hasil Uji Parsial (Uji t)

\begin{tabular}{lll} 
Variabel & $\mathrm{t}$ & Signifikansi \\
Bebas & Hitung & \\
\hline $\begin{array}{l}\text { Motivasi } \\
\text { Kerja }\end{array}$ & 8.077 & 0.000 \\
$\begin{array}{l}\text { Kepuasan } \\
\text { Kerja }\end{array}$ & 3.424 & 0.001 \\
\hline
\end{tabular}

Sumber: Data Primer (diolah dengan program SPSS 25)

Berdasarkan tabel dapat diketahui bahwa:

a. Hasil dari uji hipotesis mengenai variabel motivasi menghasilkan nilai $\mathrm{t}$ hitung sebanyak 8,077 yang lebih besar dari $t$ tabel 1,99394 dan Signifikansi sebesar 0,000 lebih kecil dari $0,05(0,000<0,05)$, yang berarti pengembangan karir berpengaruh signifikan terhadap kepuasan kerja karyawan. Hipotesis 1 yang menyebutkan bahwa "Motivasi kerja berpengaruh signifikan terhadap kinerja kerja karyawan PT. KarangMas 
Unggul (KMU)" dapat dikatakan diterima.

2. Hasil uji hipotesis untuk variabel kepuasan kerja diperoleh nilai $\mathrm{t}$ hitung sebesar 4,554 lebih besar dari t tabel 1,99394 dan signifikansi sebesar 0,001 lebih kecil dari $0,05(0,000<0,05)$, yang berarti kompensasi sangat berpengaruh terhadap kepuasan kerja karyawan. Hipotesis 2 yang menyatakan bahwa "Kepuasan kerja berpengaruh signifikan terhadap kinerja kerja karyawan terhadap PT. KarangMas Unggul (KMU)" berarti diterima.

\section{Pembahasan Hasil Penelitian}

Berdasarkan hasil yang telah diperoleh dari hasil uji regresi dan hipotesis, maka dapat peneliti jelaskan satu demi satu pengaruh dari variable bebas terhadap variable terikat, yaitu:

Pengaruh Motivasi Kerja Terhadap Kinerja Karyawan

Melihat hasil dari uji koefisien regresi dan uji $t$ pada hasil penelitian ini menunjukkan bahwa motivasi kerja yang dimiliki oleh para karyawan berpengaruh positif dan juga signifikan akan kinerja dari para karyawan di PT Karang Mas Unggul Bekasi. Berdasarkan penjelasan ini, berarti kinerja yang baik dapat diperoleh oleh setiap karyawan, apabila para karyawan tersebut memiliki motivasi atau termotivasi untuk selalu bekerja dengan semangat yang tinggi maka tentunya juga dapat mengalami peningkatan pada kinerja mereka.

Pengaruh Kepuasan Kerja Terhadap Kinerja Karyawan

Dari hasil yang telah didapatkan melalui uji koefisien regresi linear berganda maupun uji t yang telah dilakukan dalam penelitian ini, maka dapat dijelaskan bahwa variable kepuasan kerja juga memiliki pengaruh yang positif serta signifikan terhadap variable kinerja yang dimiliki oleh para karyawan di PT. Karang Mas Unggul Bekasi.

Berdasarkan hasil dan penjelasan di atas menunjukkan kinerja karyawan yang baik dapat diperoleh oleh semua karyawan secara personal, apabila para karyawan mendapatkan kepuasan kerja yang sesuai dengan keinginan masing-masing dari mreka, sehingga tentu mudah untuk mendapatkan peningkatan kinerja para karyawan.

\section{KESIMPULAN}

Berdasarkan hasil penelitian dan pembahasan poin sebelumnya maka perlu disimpulkan untuk hal-hal seperti variable motivasi kerja yang memiliki pengaruh yang positif dan signifikan terhadap kinerja yang dimiliki karyawan PT. Karang Mas Unggul Bekasi. Sehingga dapat dikatakan bahwa motivasi kerja yang tinggi akan sangat berpengaruh pada kinerja dari karyawankaryawan tersebut. 
Variable kepuasan kerja memiliki pengaruh positif dan signifikan akan kinerja para karyawan bagian lapangan PT Karang Mas Unggul Bekasi. Yang berarti, kepuasan kerja yang tinggi pula yang akan memiliki dampak besar akan adanya kinerja karyawankaryawan tersebut.

\section{REFERENSI}

Daly. (2015). Pengarub Kompetensi, Disiplin dan Kompensasi Terhadap Kinerja Pegawai Badan Pemberdayaan Perempuan dan Keluarga Berencana Daerah Provinsi Sulawesi Tengah. e-Jurnal Katalogis, Volume 3 Nomor 1, Januari 2015 hlm 84-94 ISSN: 2302-2019. Sulawesi Tengah

Dessler, G. (2014), Manajemen Sumber Daya Manusia, jilid 1 (terjemahan), PT Indeks, Jakarta.

Farchan, F. (2016). Teknikal Manajemen Sumber Daya Manusia Strategik Sebuah Paradigma Pengukuran Kinerja. Risâlah, Jurnal Pendidikan dan Studi Islam, 3(1), 42-62.

Ghozali, I. (2013). Aplikasi Analisis Multivariat dengan Program IBM SPSS 21.Edisi sia7, Penerbit Universitas Diponegoro, Semarang.

Ghozali, I. (2016). Aplikasi Analisis Multivariate dengan Program SPSS ,
Edisi Kedelapan. Semarang: Badan Penerbit Universitas Diponegoro.

Yusuf, H. A. (2016). Pemahaman Manajemen Sumber Daya Manusia. Buku Seru, Yogyakarta.

Handoko, B. (2014). Determinan Kepuasan Kerja Karyawan Pada PT. X Medan. Jurnal Ilmiah Manajemen dan Bisnis, 14(01).

Hasibuan, Malayu. S. P. (2014). Manajemen Sumber Daya Manusia (Edisi Revisi). Jakarta: Bumi Aksara.

Hasibuan, Malayu. S.P. (2013). Manajemen Sumber Daya Manusia. Jakarta: PT Bumi Aksara.

Khumaedi, Evawati. (2016). Pengarub Disiplin Dan Motivasi Kerja Terbadap Kinerja Pegawai Pada Dinas Sentra Operasi Terminal PT.Angkasa Pura II. Jurnal Ilmiah Manajemen dan Bisnis Vol 2 No 1, Hal 66 -77.

Lestari, D., \& Irbayuni, S. (2017). Analisis kinerja karyawan bagian produksi” water base "PT. Cat Tunggal Djaja Indah. Manajemen Bisnis-MEBIS, 1(2).

Mangkunegara, A.A Prabu Anwar. (2013). Manajemen Sumber Daya Manusia Perusabaan. Bandung: Remaja Rosdakarya. 
Mangkunegara, A.A. Prabu Anwar. (2015). Manajemen Sumber Daya Manusia Perusabaan. Cetakan keduabelas. Bandung: PT Remaja Rosdakarya.

Mulyadi. (2015). Manajemen Sumber Daya Manusia. Bogor: In Media.

Priyatno, D. (2014). SPSS 22 Pengolah Data Terpraktis. Andi. Yogyakarta.

Purnomo, C.A.H, Mayowan, M.D.Y. (2017). Pengaruh Motivasi Kerja Dan Disiplin Kerja Terhadap Kinerja Karyawan PT Karoseri Tentrem Sejabtera Kota Malang. Jurnal Administrasi Bisnis .Vol. 48 No 1.

Putra, A. K., \& Frianto, A. (2018). Pengaruh motivasi intrinsik dan motivasi ekstrinsik terhadap kepuasan kerja. BISMA (Bisnis dan Manajemen), 6(1), 59-66.

Rukhayati.(2018). Pengarub Motivasi Dan Disiplin Kerja Terbadap Kinerja Karyawan Di Puskesmas Talise. Jurnal Sinar Manajemen Vol 5, No 2.

Sarjono, H., \& Julianita, W. (2011). SPSS vs LISREL: sebuah pengantar, aplikasi untuk riset. Jakarta: Salemba Empat, 5(2), 23-34.

Setyati, S. (2014). Pengaruh Kepemimpinan Kepala Sekolah, Motivasi Kerja, dan Budaya Sekolah Terhadap Kinerja Guru. Jurnal Pendidikan Teknologi Dan Kejuruan, 22(2), 200-207. https://doi.org/DOI: http://dx.doi.org/10.21831/jptk.v2 $2 \mathrm{i} 2.8931$

Sousa Simoes, R.S. Costa; Riana, Gede; Subudi, Made. (2017). Pengaruh Motivasi Kerja Dan Disiplin Diri Terbadap Kepuasan Dan Kinerja Karyawan Kantor Kabupaten Ainaro Timor Leste. E-Jurnal Ekonomi dan Bisnis Universitas Udayana, [S.I.], p. 3463-3476, oct. 2017. ISSN 23373067

Sugiyono, P. D. (2014). Populasi dan sampel. Metode Penelitian Kuantitatif, Kualitatif dan R\&D, 291, 292.

Sugiyono, P. D. (2016). Metode Penelitian Kuantitatif, Kualitatif dan R\&D. Bandung: Alfabeta.

Sugiyono, P. D. (2017). Metode Penelitian Bisnis: Pendekatan Kuantitatif, Kualitatif, Kombinasi, dan R\&D. Penerbit CV. Alfabeta: Bandung.

Sutrisno, Fathoni, A., Minarsih, M.M. (2016). 'Pengarub Motivasi dan disiplin Kerja Terbadap Kinerja Pegawai di Kantor Satuan Polisi Pamong Praja Kota Semarang”. Volume 2, Nomor 2.

Sutrisno, Fathoni, A., Minarsih, M.M. (2016). 'Pengarub Motivasi dan disiplin Kerja Terbadap Kinerja Pegawai di Kantor Satuan Polisi Pamong Praja Kota Semarang". Volume 2, Nomor 2.

Wibowo, I., Riana, G., \& Putra, M. S. (2015). Pengaruh Stres Kerja Terhadap Kepuasan Kerja Dan 
Nidhomul Haq, Vol 5 No 2 Tahun 2020

Komitmen Organisasional

Karyawan. E-Jurnal Ekonomi dan

Bisnis Universitas Udayana, 4(2), 125-

145.

Wijaya, T. (2015). Pengaruh motivasi dan kompensasi terhadap kinerja karyawan pada PT Sinar Jaya Abadi Bersama. Agora, 3(2), 37-45.

Yusaini, Y. (2020). Kontribusi Budaya, Kepemimpinan, Kepuasan Kerja, Dan Komitmen Dalam Peningkatan Kinerja Dosen. Nidhomul Haq: Jurnal Manajemen Pendidikan Islam, 5(1), 3245. 